\title{
REKAYASA E-AQUACULTURE UNTUK PEMANTAUAN TAMBAK UDANG SECARA REALTIME DENGAN MODEL MULTIPOINT NODE
}

\author{
Muhamad Komarudin ${ }^{* 1}$, Hery Dian Septama ${ }^{2}$, Titin Yulianti ${ }^{3}$, Muhamad Aby Wicaksono ${ }^{4}$ \\ 1,2,3,4 Teknik Informatika, Fakultas Teknik Universitas Lampung \\ Email: ${ }^{1}$ komar@eng.unila.ac.id, ${ }^{2}$ hery@eng.unila.ac.id, ${ }^{3}$ titin.yulianti@eng.unila.ac.id, \\ ${ }^{4}$ muhammad.aby1001@students.unila.ac.id \\ *Penulis Korespondensi
}

(Naskah masuk: 24 September 2020, diterima untuk diterbitkan: 22 Maret 2020)

\begin{abstract}
Abstrak
Udang merupakan salah satu komoditas unggulan bagi Indonesia dari sektor perikanan. Budidaya udang pada tambak, perlu memperhatikan kualitas air. Kualitas air yang perlu diperhatikan dalam pertumbuhan dan kehidupan udang adalah perubahan temperatur, kadar garam, kebutuhan oksigen dan tingkat keasaman atau kandungan $\mathrm{pH}$. Pemantauan secara manual membutuhkan waktu, tenaga dan biaya yang jauh lebih besar karena harus ada petugas yang berkeliling kolam untuk melakukan pengukuran. Dengan Internet of Things (IoT) yang dikembangkan dalam penelitian ini proses monitoring tersebut dapat dilakukan dengan cepat atau realtime. Model yang dikembangkan terdiri dari perangkat node yang dipasang pada setiap kolam dan masterboard untuk pengumpulan data. Sensor yang dipasang pada setiap node adalah sensor salinitas air, sensor $\mathrm{pH}$ dan sensor suhu. Nilai salinitas, $\mathrm{pH}$ dan suhu selain ditampilkan pada perangkat penampil yang ada pada node juga dikirimkan ke masterboard. Hasil penelitian menunjukkan perangkat sensor bekerja dengan baik, data salinitas air, pH dan suhu dapat ditampilkan pada node. Ujicoba komunikasi data juga dapat berkerja dengan baik yang ditunjukkan dengan data dapat dikirimkan ke masterboard dengan delay 1 detik karena data masuk secara bergantian atau serial. Masterboard dapat bekerja untuk mengirimkan data ke basis data cloud firebase untuk selanjutnya data ditampilkan pada aplikasi monitoring yang telah dikembangkan.
\end{abstract}

Kata kunci: pemantauan, tambak udang, e-aquaculture

\section{DESIGN OF E-AQUACULTURE FOR REALTIME SHRIMP POND MONITORING WITH MULTIPOINT NODE MODELS}

\begin{abstract}
Shrimp is one of the leading commodities for Indonesia from the fisheries sector. Shrimp farming, needs to pay attention to pond water quality. The water quality parameter that needs to be considered in the growth and life of shrimp is temperature, salinity, and $\mathrm{pH}$. The farmer usually, monitor the shrimp pond manually that requires much greater time, effort and cost. The process can be automated with the Internet of Things (IoT) developed in this research. The model developed consists of a set of nodes installed in each pond and a masterboard for data collection. The sensors installed at each node are water salinity sensors, $p H$ sensors and temperature sensors. The Salinity, $\mathrm{pH}$ and temperature score besides being displayed on the display device at each node, it is also sent to the masterboard through data communication. The results show that the sensor and data communication devices can work well with low latency (1 s) since the data received serially. Masterboard can work to send data to the Firebase cloud database so that the data may displayed in the monitoring application that has been developed.
\end{abstract}

Keywords: monitoring, shrimp pond, e-aquaculture

\section{PENDAHULUAN}

Udang merupakan salah satu komoditas unggulan bagi Indonesia dari sektor perikanan. Udang memiliki nilai ekspor sekitar US\$ 1,5 miliar, yang lebih tinggi dibandingkan ikan sebesar US\$ 1 miliar dan rumput laut US\$ 0,2 miliar (Wuryani, Meilani, 2011). Dengan banyaknya usaha tambak udang, sering pula juga terjadi beberapa masalah seperti gagal panen yang diakibatkan oleh beberapa penyakit udang seperti white spot syndrome virus (WSSV), myo, dan white feces disease (WFD) (Yanti, Herliany, Negara, and Utami, 2017). Penyakit-penyakit itu dapat menyebabkan kegagalan dalam budidaya udang karena menyerang pada 
semua umur udang. Selain penyakit, cuaca yang tidak menentu juga dapat mengakibatkan kualitas air ditambak udang menjadi buruk sehingga mempengaruhi pertumbuhan udang. Buruknya kualitas air berdampak pada turunnya nafsu makan udang dan lambatnya pertumbuhan udang. Sehingga dibutuhkan perhatian yang lebih untuk mempertahankan kualitas air di tambak udang. Kualitas air yang perlu diperhatikan dalam pertumbuhan dan kehidupan udang adalah perubahan temperatur, kadar garam, kebutuhan oksigen dan derajat keasaman atau kandungan $\mathrm{pH}$ (Potential of Hydrogen) pada air.

Pemantauan kualitas air pada tambak udang sering dilakukan secara manual yakni pengukuran berkala setiap pagi dan sore dengan menggunakan alat ukur yang dilakukan oleh petambak. Proses pemantauan demikian cenderung tidak praktis, membutuhkan upah pekerja yang tinggi serta tingkat kesalahan manusia yang tinggi. Dengan kemajuan di bidang teknologi informasi, sekarang data kualitas air dapat di ambil melalui sensor-sensor untuk kemudian dikumpulkan ke dalam server untuk selanjutnya diolah dan divisualisasikan.

Berdasarkan permasalahan di atas maka dalam penelitian ini dirancang sistem pemantauan kualitas air pada tambak udang untuk mendukung konsep $e$ Aquaculture. e-Aquaculture sendiri merupakan konsep penerapan teknologi informasi dan komunikasi dalam bidang atau sektor perikanan. Sistem yang akan dibangun terdiri single board mini computer Arduino (Margolis, Jepson, Weldin, 2020) dan beberapa sensor untuk pemantauan suhu, $\mathrm{pH}$, serta salinitas pada tambak udang yang dipasang pada tiap node. Node secara aktif mengirimkan data ke masterboard. Masterboard terdiri dari Arduino dan modul komunikasi radio serta internet. Selanjutnya masterboard akan secara aktif mengirimkan data yang diterima dari tiap node ke cloud basis data. Model ini dilakukan untuk menekan biaya untuk kebutuhan akses data langsung ke internet.

\section{METODE PENELITIAN}

Metode Prototyping adalah salah satu versi rekayasa sistem yang dilakukan secara bertahap dan dikomunikasikan antara para pengembang dan calon pengguna. Setiap tahapan secara cepat dapat memberikan gambaran kepada pengguna bagaimana sistem berkerja meskipun belum seluruh bagian selesai. Proses pembuatan prototype ini disebut prototyping. Dengan menggunakan metode ini maka setiap langkah dilakukan untuk membuat protoype secepat mungkin untuk dapat dikomunikasikan ke pengguna sehingga memperoleh umpan balik dari pengguna untuk memperbaiki prototype yang telah dikembangkan. Metode prototyping memiliki alur yang dapat dilihat pada Gambar 1 (Pressman, 2005).

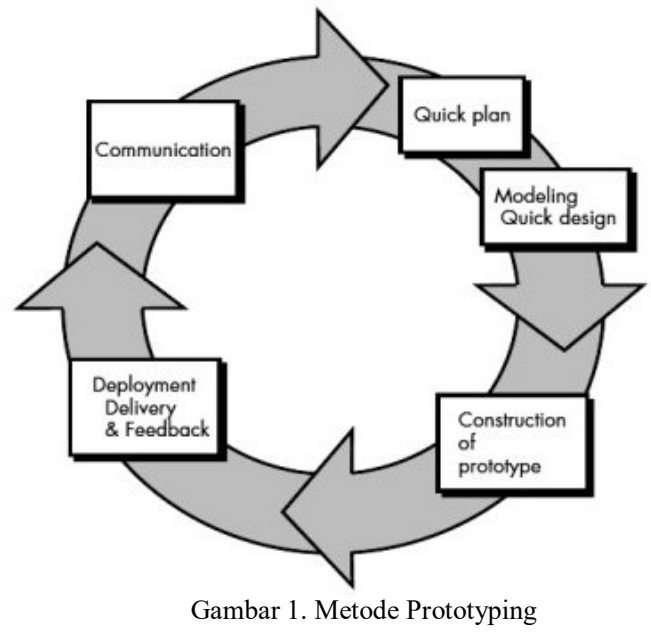

Model prototyping akan digunakan dalam penelitian ini untuk merancang dan mengimplementasikan sistem pemantauan kualitas air tambak udang dengan model multipoint node. Dengan menggunakan metode ini diharapkan proses pengerjaaan sistem yang dikembangkan dapat dilakukan dalam waktu yang singkat dan sesuai dengan kebutuhan petambak. Tahapan pada model protyping ini terdiri dari quick plan, modelling and quick design, construction of prototype, deployment delivery and feedback dan terakhir adalah communication. Proses pengerjaan dilakukan beberapa kali iterasi sehingga bentuk akhir yang diinginkan pengguna dapat dipenuhi.

\section{TINJAUAN PUSTAKA}

\subsection{Udang dan Kualitas Air}

Udang merupakan salah satu komoditas unggulan bagi Indonesia dari sektor perikanan. Salah satu jenis udang yang dikembangbiakkan di Indonesia yaitu udang vanname. Budidaya udang vanname harus memperhatikan beberapa faktor sehingga dapat di panen secara maksimal. Kelangsungan hidup udang salah satu faktornya adalah terkait dengan kualitas air tambak. Parameter tersebut antara lain adalah $\mathrm{pH}$ atau derajat keasaman air, kandungan oksigen terlarut, kadar garam pada air atau salinitas, tingkat kecerahan air tambak, pada setiap kolam (Fuady, Haerudin, Nitisupardjo, 2013).

Sedangkan pada penelitian budidaya semi intensif pada udang diperoleh beberapa parameter kualitas air yang maksimal bagi pertumbuhan udang antara lain: kandungan oksigen terlarut pada kolam berkisar antara 1,8 - 3,5 mg/l, tingkat keasaman air atau $\mathrm{pH}$ antara 5,63 - 6,64, nilai suhu air kolam 26 ${ }^{0} \mathrm{C}-29{ }^{0} \mathrm{C}$, serta kandungan garam pada air atau salinitas berkisar antara $16-18$ ppt (Pratama, Wardiyanto, Supono, 2017).

\subsection{Internet of Things (IoT)}

Internet of things (IoT) merupakan suatu konsep yang dimana terdapat objek tertentu mempunyai kemampuan untuk melakukan transfer 
data lewat suatu jaringan tanpa adanya proses interaksi dari manusia ke manusia ataupun dari manusia ke perangkat komputer. Dengan menggunakan IoT seseorang dapat melakukan interaksi dengan suatu objek dengan jarak jauh .

Pada dasarnya suatu sistem dapat dikatakan IoT, harus memenuhi minimal 4 komponen yaitu yang pertama harus memiliki perangkat/sensor yang berfungsi untuk mendapatkan dan mengumpulkan data dari lingkungan. Setelah itu yang kedua harus memiliki konektivitas yang berfungsi untuk mengirim data yang didapat yang kemudian disimpan ke suatu cloud atau server. Selanjutnya setelah data sampai ke cloud, data akan diproses menggunakan perangkat lunak tertentu. Komponen terakhir yang harus dimiliki yaitu user interface, hasil informasi akan di tampilkan dengan cara tertentu agar bermanfaat bagi pengguna (Solanki, Diaz, Davim, 2019).

Sistem adalah suatu kesatuan dari beberapa komponen yang dirangkai menjadi satu bagian untuk menemukan tujuan yang sama. Pemantauan adalah proses yang dilakukan secara terus-menerus dalam pengumpulan data dan pengukuran atau pemantauan suatu data. Sistem pemantauan kualitas air merupakan suatu alat yang dirangkai dari berbagai macam komponen yang difungsikan untuk melakukan pemantauan data kualitas air yang didapatkan. Dalam penelitian ini, kualitas air yang diukur untuk pemantauan tambak udang yaitu suhu, $\mathrm{pH}$, dan salinitas air. (Kusrini, Wiranto, Syamsu, and Hasanah, 2016).

Penelitian serupa telah dilakukan dengan mengukur parameter kualitas air pada tambak udang, tahap awal dilakukan di desa Sriminosari sebatas parameter $\mathrm{pH}$ dan suhu. Pemantauan tersebut dilakukan secara online sehingga informasi dari kondisi air tambak di beberapa tambak terukur secara real time. Purwarupa IoT yang dikembangkan terdiri dari mikrokontroler NodeMCU V3 Lolin sebagai unit pemroses dan router berbasis modem WiFi 4G Telkomsel Wingle Softwifi Hotspot untuk mengirimkan data ke internet (Setiawan, Juliasih, Abdullah, 2019). Penelitian monitoring tambak udang juga dilakukan dengan menggunakan arduino dan sensor untuk mendapatkan data kualitas air yang selanjutnya dikirimkan ke internet untuk dapat ditampilkan pada aplikasi Blynk (Pauzi, Syafira, Surtono, Supriyanto, 2017).

Konsep pengembangan monitoring secara realtime untuk mendukung konsep revolusi industri 4.0 khususnya dibidang perikanan digagas juga dengan konsep IoT (Junaidi, Kartiko, 2020). Konsep yang ditawarkan terdiri dari sensor yang terhubung dengan NodeMCU untuk memantau kualitas air kolam. NodeMCU kemudian mengirimkan data langsung ke basis data di internet. Data yang tersimpan pada basis data kemudian dapat ditampilkan hasilnya pada aplikasi pemantauan.
Dengan demikian data dapat dilihat secara realtime oleh petambak.

Penelitian tersebut akan diperbaiki pada penelitian ini. Untuk menghemat daya dan kebutuhan akses internet maka digunakan model multipoint node dan masterboard. Perangkat node digunakan untuk melakukan pengumpulan data di setiap kolam yang dipantau. Node kemudian mengirimkan data ke masterboard lewat komunikasi radio. Masterboard dapat dihubungkan dengan internet untuk mengirimkan data agar bisa diakses lebih luas. Dengan demikian maka kebutuhan daya bisa diminimalisir dan kebutuhan akses internet cukup dilakukan oleh satu perangkat saja yakni pada masterboard.

\section{PENGEMBANGAN SISTEM}

\subsection{Quick Plan}

Pada tahap awal ini dilakukan pengumpulan kebutuhan dari sistem yang akan digunakan. Kebutuhan-kebutuhan tersebut didapat berdasarkan studi literatur yang dilakukan dan proses komunikasi dengan petambak mengenai apa saja kebutuhan untuk pemantauan tambak udang yang akan dikembangkan. Terdapat beberapa kebutuhan yang telah dikumpulkan yaitu:

- Alat yang akan dibangun dapat mengukur kadar $\mathrm{pH}$, Suhu, dan salinitas pada air di tambak udang.

- Dibutuhkan minimal 2 node untuk dilakukan uji coba di setiap titik pada tambak udang.

- Data pada setiap node harus dikirim dan dikumpulkan ke satu masterboard untuk menampung data dari setiap node, selanjutnya data dikirim ke server. Hal ini dilakukan untuk mengurangi penghematan daya dan penghematan penggunaan kuota internet.

\subsection{Modelling and Quick Design}

Setelah diketahui kebutuhan yang diperlukan dalam proses perancangan sistem, maka dilakukan perancangan dan pemodelan prototype. Adapun rangkaian dari prototipe yang akan dirancang ditunjukkan pada gambar 2. Sistem di desain dengan menggunakan model masterboard dan node yang dipasang pada tiap kolam. Pada setiap node terdiri dari satu single board mini computer arduino uno dan beberapa sensor seperti $\mathrm{PH}$ meter Detector Sensor PH-4502C yang berfungsi untuk mengambil data $\mathrm{pH}$ air, Sensor Suhu DS18B20 yang berfungsi untuk mengambil data suhu air, Sensor Salinitas berfungsi untuk mengambil data kadar garam pada air. 


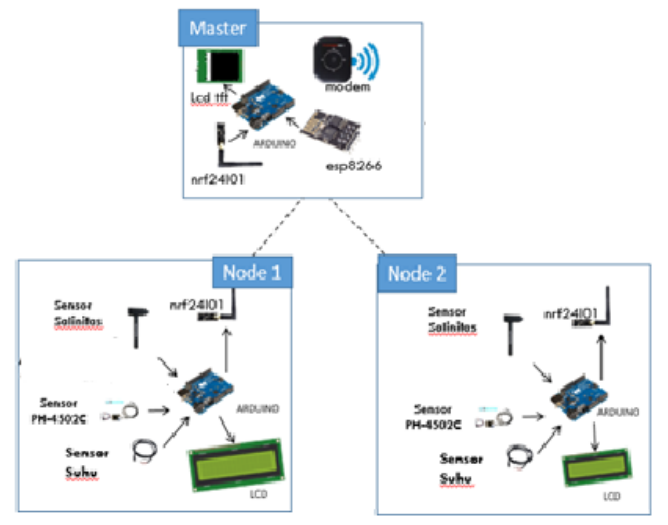

Gambar 2 Rancangan arsitektur Sistem

Data dari setiap node sensor dikirimkan ke masterboard menggunakan pemancar nRF24L01. Masterboard kemudian dapat mengirimkan data ke basis data Firebase (Yahioui, 2017) melalui API menggunakan jaringan Wireless Fidelity (WiFi). Terdapat 2 node yang bekerja mengambil data kualitas air pada setiap titik tambak udang. Data diambil setiap 5 menit dan langsung akan dikirimkan ke masterboard untuk dikumpulkan. Data kemudian dapat ditampilkan pada aplikasi pemantauan berbasis android (Moroney, 2017) yang telah dibuat.

\subsection{Construction of Protoype}

Pada tahap awal pengerjaan penelitian ini dilakukan perancangan sistem pemantauan tambak udang dengan merakit komponen-komponen sesuai yang telah di desain sebelumnya. Sistem pemantauan tambak udang ini terdiri dari dua node yang pada setiap node terdiri dari beberapa komponen yaitu sensor $\mathrm{pH}$, sensor suhu dan sensor salinitas, nrf24101 dan LCD 20x4 display beserta modul I2C.

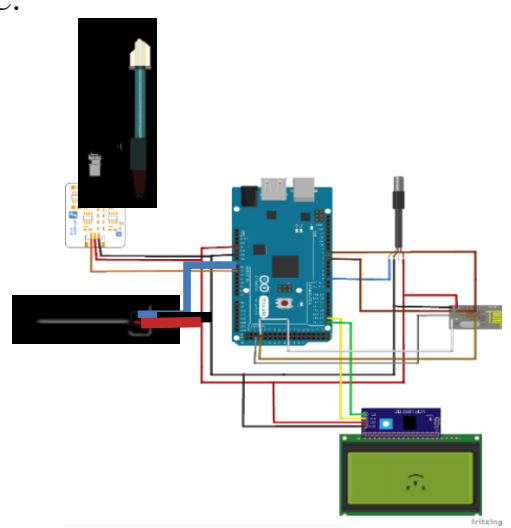

Gambar 3 Wiring diagram node sistem pemantauan kualiatas air tambak udang

Semua komponen tersebut terhubung ke Arduino uno sebagai pemroses data. Untuk sumber tegangan pada sistem ini menggunakan sumber tegangan dari baterai. Gambar 3 menunjukkan wiring diagram untuk perangkat node pada sistem pemantauan kualitas air pada tambak udang.

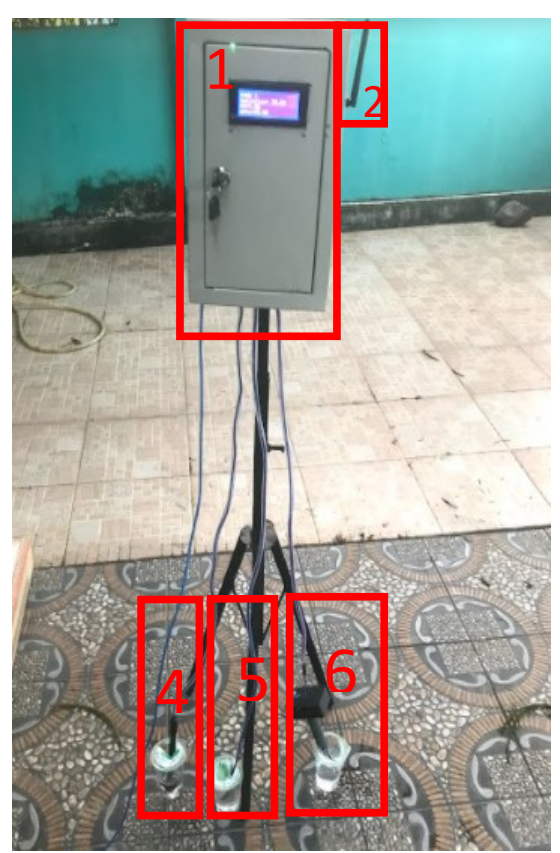

Gambar 4 Bagian node pada perangkat sistem pemantauan kualitas air tambak udang tampak dari luar

Pada gambar 4 merupakan implementasi dari perangkat node 1 sistem pemantauan kualitas air tambak udang yang digunakan untuk mengukur kualitas air pada tambak udang. Pada kotak merah bernomor 1 terdapat kotak panel yang berfungsi untuk menyimpan komponen-komponen dan perangkat pada sistem. Pada kotak nomor 2 merupakan nrf24101 yang berfungsi untuk mengirim data dari node ke masterboard. Pada kotak nomor 4 merupakan sensor $\mathrm{pH}$ yang berfungsi untuk mengukur $\mathrm{pH}$ air. Pada kotak nomor 5 merupakan sensor DS18B20 yang berfungsi untuk mengukur suhu pada air tambak udang. Pada kotak nomor 6 merupakan sensor salinitas yang berfungsi untuk mengukur kadar garam pada air tambak udang.

Pada gambar 5 merupakan detail komponenkomponen perangkat node pada sistem pemantauan kualitas air tambak udang yang diletakan didalam box panel. Pada kotak merah bernomor 1 merupakan Arduino uno berfungsi sebagai single board mini computer untuk memproses data yang telah diambil pada sensor-sensor. Kemudian pada kotak nomor 2 merupakan modul dari sensor $\mathrm{pH}$ dan sensor suhu yang terhubung ke Arduino uno. Pada kotak nomor 3 merupakan nrf24101 yang terhubung ke Arduino uno. Nrf24101 berfungsi untuk mengirim data pada yang didapat dari node ke masterboard. Setiap node kemudian dipasang pada kolam untuk dapat memantau kondisi kualitas air tambak secara realtime. Sensor-sensor yang terpasang masih dapat ditambahkan untuk pengembangan lebih lanjut sesuai kebutuhan dari tiap tambak udang yang akan dipantau kondisinya. 


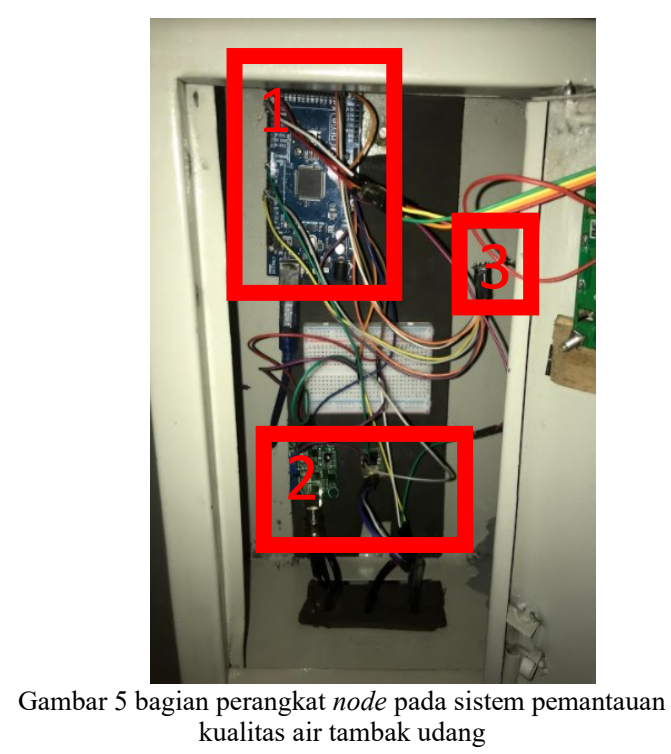

Selanjutnya pada masterboard terdiri dari beberapa komponen yaitu nrf24101, lcd 20x4 display beserta modul I2C dan modul Wemos D1. Untuk sumber tegangan pada sistem ini menggunakan sumber tegangan dari baterai. Gambar 6 menunjukkan wiring diagram untuk perangkat masterboard pada sistem pemantauan kualitas air pada tambak udang.

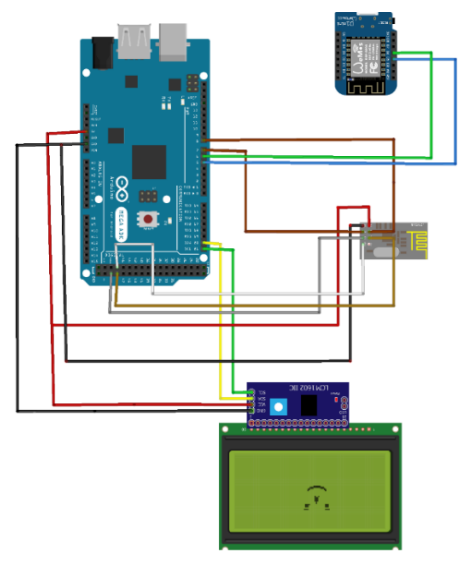

Gambar 6 Diagram masterboard sistem pemantauan kualitas air tambak udang

Pada gambar 7 merupakan masterboard yang digunakan untuk menerima data dari setiap node dan mengirimkannya internet. Masterboard akan diletakan di karea yang terjangkau internet dengan baik agar data yang diterima dari node dapat langsung terkirim ke internet. Pada kotak merah nomor 1 terdapat lcd 20x4 yang berfungsi untuk menampilkan data yang di terima dari setiap node dan pada kotak merah nomor 2 terdapat nrf24101 yang berfungsi menerima data dari setiap node.
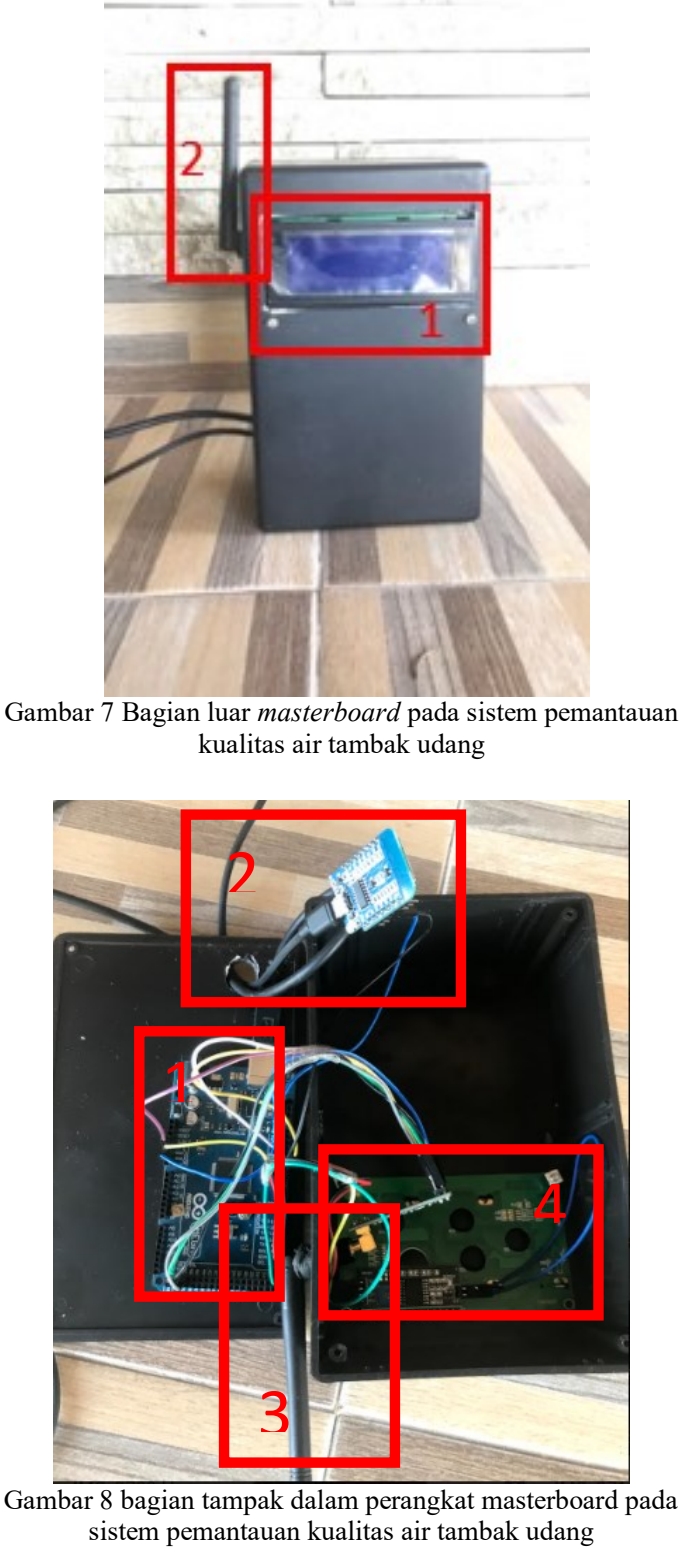

Pada gambar 8 merupakan komponenkomponen pada masterboard Sistem pemantauan kualitas air tambak udang. Pada kotak merah nomor 1 merupakan Arduino mega sebagai controller pada perangkat masterboard. Pada kotak nomor 2 merupakan modul Wemos D1 berfungsi sebagai perangkat koneksi internet. Pada kotak nomor 3 merupakan nrf24101 yang terhubung langsung ke Arduino mega. Pada kotak nomor 4 merupakan lcd 20x4 beserta modul i2c yang tehubung langsung ke Arduino mega.

\subsection{Deployment Delivery and Feedback}

Pengambilan data dilakukan di Tambak udang PB Tunas Baru Jalan Pesisir Canti, Desa Canti Kecamatan Kalinda Kabupaten Lampung Selatan ditunjukkan pada gambar 10. Perangkat node sistem pemantauan kualitas air tambak udang dipasang dipinggir tiap kolam tambak udang dan sensorsensor dimasukkan ke dalam air lokasi kolam 
tambak udang yang akan dipantau. Perangkat node yang dipasang ditunjukkan pada gambar 4 di atas.

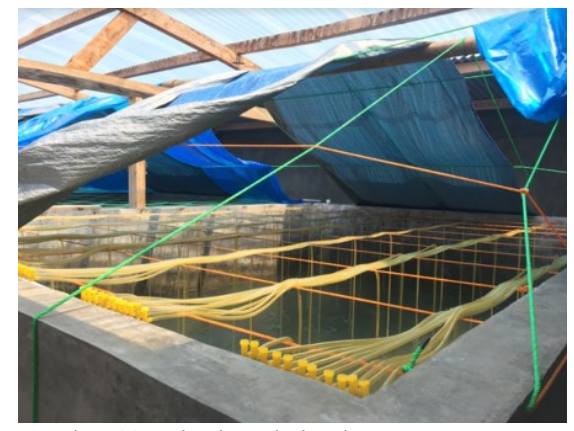

Gambar 10 Lokasi tambak udang PB Tunas Baru

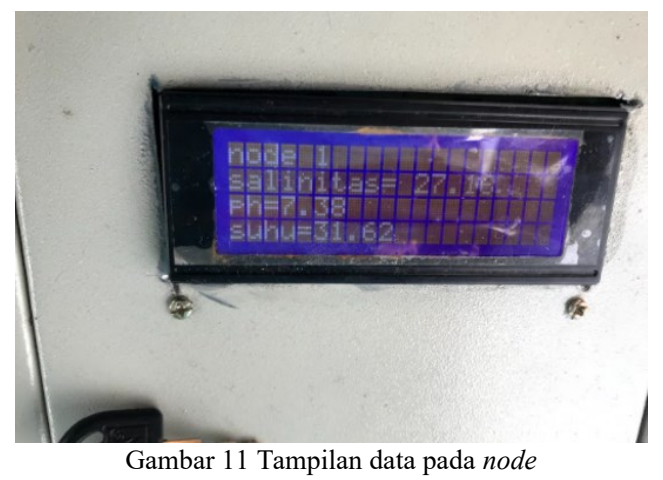

Gambar 11 menunjukkan data kualitas air yang didapat dari sensor dan ditampilkan pada LCD display di setiap node. Data salinitas air, suhu dan $\mathrm{pH}$ kolam di setiap node diambil setiap 5 menit sekali dan ditampilkan pada layar display tersebut. Selanjutnya melalui perangkat radio node mengirimkan data yang didapat dari sensor kepada masterboard yang diletakkan disekitar tambak.

Tabel 1 menunjukkan data dari kualitas air tambak udang yang sedang dipantau oleh sistem. Data diambil dengan interval setiap 5 menit sekali dalam durasi pengambilan data selama 100 menit. Ketiga sensor aktif bekerja untuk mendapatkan data kualitas air dan ditampilkan pada node serta dikirimkan ke masterboard.

Tabel 1 Pengambilan data suhu, salinitas dan $\mathrm{pH}$ pada node 1

\begin{tabular}{ccccc}
\hline No & Waktu & Suhu $\left({ }^{0} \mathbf{C}\right)$ & $\begin{array}{c}\text { Salinitas } \\
(\mathbf{P p t})\end{array}$ & $\begin{array}{c}\text { Keasaman } \\
(\mathbf{p H})\end{array}$ \\
\hline 1 & $13: 25$ & 31 & 30 & 7.3 \\
2 & $13: 30$ & 31 & 30 & 7.3 \\
3 & $13: 35$ & 31 & 30 & 7.3 \\
4 & $13: 40$ & 31 & 30 & 7.3 \\
5 & $13: 45$ & 31 & 31 & 7.3 \\
6 & $13: 50$ & 31 & 31 & 7.3 \\
7 & $13: 55$ & 31 & 30 & 7.3 \\
8 & $14: 00$ & 31 & 31 & 7.3 \\
9 & $14: 05$ & 31 & 31 & 7.3 \\
10 & $14: 10$ & 31 & 32 & 7.3 \\
11 & $14: 15$ & 31 & 31 & 7.3 \\
\hline
\end{tabular}

\begin{tabular}{ccccc}
\hline No & Waktu & Suhu $\left({ }^{\circ} \mathbf{C}\right)$ & $\begin{array}{c}\text { Salinitas } \\
(\mathbf{P p t})\end{array}$ & $\begin{array}{c}\text { Keasaman } \\
(\mathbf{p H})\end{array}$ \\
\hline 12 & $14: 20$ & 31 & 31 & 7.3 \\
13 & $14: 25$ & 31 & 31 & 7.3 \\
14 & $14: 30$ & 31 & 31 & 7.3 \\
15 & $14: 35$ & 31 & 31 & 7.3 \\
16 & $14: 40$ & 31 & 31 & 7.3 \\
17 & $14: 45$ & 31 & 31 & 7.3 \\
18 & $14: 50$ & 31 & 32 & 7.3 \\
19 & $14: 55$ & 31 & 31 & 7.3 \\
20 & $15: 00$ & 31 & 31 & 7.3 \\
\hline
\end{tabular}

Tabel 2 menampilkan data yang diterima oleh masterboard dari node 1 dan node 2 yang telah dipasang pada kolam tambak udang dilokasi pemantauan. Berdasarkan data yang didapat antara kedua node tidak terdapat perbedaan yang signifikan. Dapat dilihat bahwasannya waktu tunda (delay) antara node 1 dan node 2 adalah 1 detik dari 40 data yang terkirim ke masterboard selama 100 menit pengambilan data. Hal ini disebabkan masterboard menggunakan Arduino mega. Arduino mega tidak bisa menerima data secara pararel, maka dari itu penerimaan data yang masuk kedalam masterboard Arduino mega di terima secara bergantian.

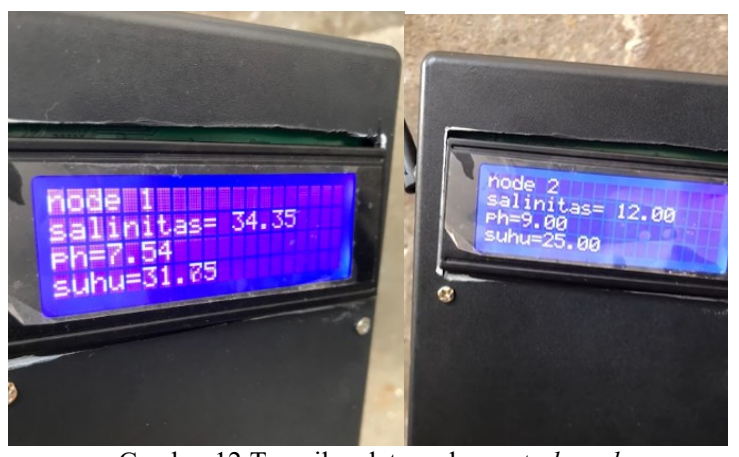

Gambar 12 Tampilan data pada masterboard

Gambar 12 menujukkan data kualitas air yang ditampilkan pada masterboard yang dikirimkan oleh masing-masing node. Data yang diperoleh dari setiap node ditampilkan secara bergantian pada masterboard.

Tabel 2 hasil data yang terkirim ke masterboard

\begin{tabular}{cccccc}
\hline No & Waktu & $\begin{array}{c}\text { Suhu } \\
\left({ }^{\mathbf{0}} \mathbf{C}\right)\end{array}$ & $\begin{array}{c}\text { Salinitas } \\
(\mathbf{P p t})\end{array}$ & $\mathbf{p H}$ & Node \\
\hline 1 & $13: 25$ & 31 & 30 & 7.3 & 1 \\
2 & $13: 25$ & 32 & 29 & 7.3 & 2 \\
3 & $13: 30$ & 31 & 30 & 7.3 & 1 \\
4 & $13: 30$ & 32 & 29 & 7.3 & 2 \\
5 & $13: 35$ & 31 & 30 & 7.3 & 1 \\
6 & $13: 35$ & 32 & 29 & 7.3 & 2 \\
7 & $13: 40$ & 31 & 30 & 7.3 & 1 \\
8 & $13: 40$ & 32 & 30 & 7.3 & 2 \\
\hline
\end{tabular}




\begin{tabular}{|c|c|c|c|c|c|}
\hline No & Waktu & $\begin{array}{c}\text { Suhu } \\
\left({ }^{\circ} \mathrm{C}\right)\end{array}$ & $\begin{array}{c}\text { Salinitas } \\
\text { (Ppt) }\end{array}$ & pH & Node \\
\hline 9 & $13: 45$ & 31 & 31 & 7.3 & 1 \\
\hline 10 & $13: 45$ & 32 & 30 & 7.3 & 2 \\
\hline 11 & $13: 50$ & 31 & 30 & 7.3 & 1 \\
\hline 12 & $13: 50$ & 32 & 29 & 7.3 & 2 \\
\hline 13 & 13:55 & 31 & 30 & 7.3 & 1 \\
\hline 14 & $13: 55$ & 32 & 30 & 7.3 & 2 \\
\hline 15 & $14: 00$ & 31 & 31 & 7.3 & 1 \\
\hline 16 & 14:00 & 32 & 30 & 7.3 & 2 \\
\hline 17 & 14:05 & 31 & 31 & 7.3 & 1 \\
\hline 18 & 14:05 & 32 & 30 & 7.3 & 2 \\
\hline 19 & $14: 10$ & 31 & 32 & 7.3 & 1 \\
\hline 20 & $14: 10$ & 32 & 31 & 7.3 & 2 \\
\hline 21 & $14: 15$ & 31 & 31 & 7.3 & 1 \\
\hline 22 & 14:15 & 32 & 30 & 7.3 & 2 \\
\hline 23 & $14: 20$ & 31 & 31 & 7.3 & 1 \\
\hline 24 & $14: 20$ & 32 & 30 & 7.3 & 2 \\
\hline 25 & $14: 25$ & 31 & 31 & 7.3 & 1 \\
\hline 26 & $14: 25$ & 32 & 30 & 7.3 & 2 \\
\hline 27 & $14: 30$ & 31 & 31 & 7.3 & 1 \\
\hline 28 & $14: 30$ & 32 & 31 & 7.3 & 2 \\
\hline 29 & $14: 35$ & 31 & 31 & 7.3 & 1 \\
\hline 30 & $14: 35$ & 32 & 30 & 7.3 & 2 \\
\hline 31 & $14: 40$ & 31 & 31 & 7.3 & 1 \\
\hline 32 & $14: 40$ & 32 & 30 & 7.3 & 2 \\
\hline 33 & $14: 45$ & 31 & 31 & 7.3 & 1 \\
\hline 34 & $14: 45$ & 32 & 29 & 7.3 & 2 \\
\hline 35 & $14: 50$ & 31 & 32 & 7.3 & 1 \\
\hline 36 & $14: 50$ & 32 & 30 & 7.3 & 2 \\
\hline 37 & $14: 55$ & 31 & 31 & 7.3 & 1 \\
\hline 38 & $14: 55$ & 32 & 30 & 7.3 & 2 \\
\hline 39 & $15: 00$ & 31 & 31 & 7.3 & 1 \\
\hline 40 & $15: 00$ & 32 & 30 & 7.3 & 2 \\
\hline
\end{tabular}

Gambar 13 merupakan aliran data sistem yang telah dibuat. Terdapat 2 node yang bekerja mengambil data kualitas air pada setiap titik tambak udang setiap 5 menit dan langsung akan dikirimkan ke masterboard seperti ditunjukkan tabel 2. Setelah data dari setiap node terkumpul di masterboard selanjutnya akan dikirim ke basis data firebase melalui API. Data yang disimpan pada basis data kemudian ditampilkan pada aplikasi berbasis android yang dikembangkan seperti ditunjukkan pada gambar 14. Jika data kualitas air dibawah batas normal maka tampilan angka pada layar akan berubah menjadi merah.

Dengan model multipoint node maka proses pengiriman data ke internet cukup dilakukan oleh masterboard saja. Hal ini dilakukan untuk dapat meminimalisir biaya dan perangkat untuk kebutuhan akses ke internet dalam hal pengiriman data.

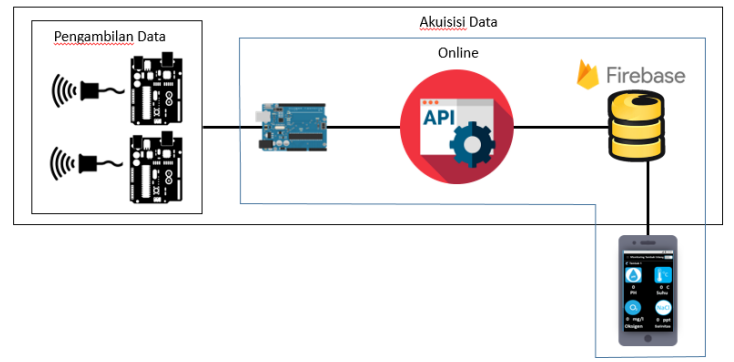

Gambar 13 Model aliran data

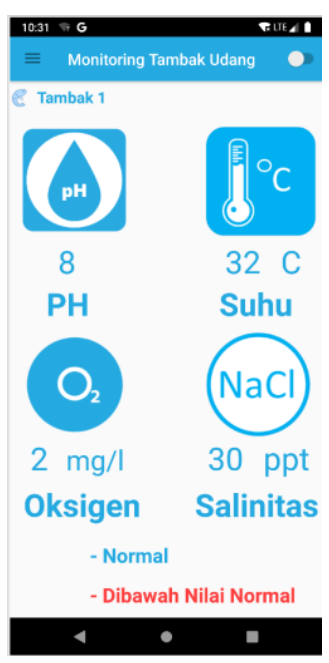

Gambar 14 Tampilan data pada aplikasi pemantauan

\section{KESIMPULAN}

Sesuai dengan hasil pengujian sistem, perangkat dengan model mutipoint node dan masterboard yang dibangun dapat bekerja dengan baik. Perangkat node dapat mengirimkan data sensor ke masterboard dengan baik. Kualitas air kolam yang dipantau masih dalam batas air yang baik untuk pertumbuhan udang. Proses pengiriman data antar node terjadi delay sebanyak 1 detik karena data masuk secara bergantian. Masterboard dapat bekerja untuk mengirimkan data ke basis data cloud firebase untuk selanjutnya data ditampilkan pada aplikasi monitoring yang telah dikembangkan.

\section{UCAPAN TERIMA KASIH}

Penulis mengucapkan terima kasih kepada Lembaga Penelitian dan Pengabdian kepada Masyarakat (LPPM) Universitas Lampung. Penelitian ini didanai oleh Hibah Penelitian Terapan DIPA BLU Unila tahun 2020

\section{DAFTAR PUSTAKA}

FUADY, M. HAERUDDIN. NITISUPARDJO, M., 2013. Pengaruh pengelolaan kualitas air terhadap tingkat kelulushidupan dan laju pertumbuhan udang vaname (litopenaeus vannamei) di PT. Indokor Bangun Desa, yogyakarta. Management of Aquatic 
Resources Journal (MAQUARES), vol 2 no 4, pp. 155-162

JUNAIDI, A. KARTIKO, C. 2020. Design of Pond Water Quality Monitoring System Based on Internet of Things and Pond Fish Market in Real-Time to Support the Industrial Revolution 4.0. IOP Conf. Series: Materials Science and Engineering 771

KUSRINI, P. WIRANTO, G. SYAMSU, I AND HASANAH, L. 2016. Sistem Monitoring Online Kualitas Air Akuakultur untuk Tambak Udang Menggunakan Aplikasi Berbasis Android," J. Elektronika dan Telekomunikasi, vol. 16, no. 2, p. 25

MARGOLIS, M. JEPSON, B. WELDIN, NR. 2020. Arduino Cookbook: Recipes to Begin, Expand, and Enhance Your Projects 3rd Edition. California: O'reilly

MORONEY, L. 2017. The Definitive Guide to Firebase: Build Android Apps on Google's Mobile Platform 1st ed. Edition. Washington: Apress

PAUZI, GA. SYAFIRA, MA. SURTONO, A. SUPRIYANTO, A. 2017. Aplikasi IoT Sistem Monitoring Kualitas Air Tambak Udang Menggunakan Aplikasi Blynk Berbasis Arduino Uno. Jurnal Teori dan Aplikasi Fisika vol. 05, no. 02, pp $1-8$

PRATAMA, A, WARDIYANTO, SUPONO. 2017. Studi performa udang vaname (litopenaeus vannamei) yang dipelihara dengan sistem semi intensif pada kondisi air tambak dengan kelimpahan plankton yang berbeda pada saat penebaran. Jurnal Rekayasa dan Teknologi Budidaya Perairan vol 6, no 1, pp. $643-652$

PRESSMAN, R. S. 2005. Software Engineering a Practititoner's Approach $6^{\text {th }}$ ed. new York: Mc Graw Hill

SETIAWAN, A. JULIASIH, N. L. G. R. ABDULLAH, W. 2019. Application of Internet of Things (IoT) Technology To Traditional Shrimp Ponds in Sriminosari Village, East Lampung," Jurnal Diseminasi Pengabdi. Kpd. Masy., vol. 1, no. 2, p. 107

SOLANKI, V.K. DÍAZ, V.G. DAVIM, V.J. 2019. Handbook of IoT and Big Data. Boca Raton: CRC Press

WURYANDANI, D. MEILANI, H. 2011. Kebijakan Pengelolaan Sumber Daya Perikanan Laut Untuk Menunjang Ketahanan Pangan di Indonesia, Jurnal Ekonomi dan Kebijakan Publik, vol. 2, no. 1, pp. 395-419

YANTI, M. E. G. HERLIANY, N. E. NEGARA, B. F., AND UTAMI, M. A. F., 2017. Deteksi molekuler white spot syndrome virus (wssv) pada udang vaname (litopenaeus vannamei) di PT. Hasfam Inti Sentosa, J. Enggano, vol. 2, no. 2, pp. 156169

YAHIAOUI, H. 2017. Firebase Cookbook. Birmingham: Packt Publishing 